\title{
Modified dilution technique to estimate viral versus grazing mortality of phytoplankton: limitations associated with method sensitivity in natural waters
}

\author{
Susan A. Kimmance ${ }^{1, *}$, William H. Wilson ${ }^{1,2}$, Stephen D. Archer ${ }^{1}$ \\ ${ }^{1}$ Plymouth Marine Laboratory, Prospect Place, Plymouth PL1 3DH, UK \\ ${ }^{2}$ Present address: Bigelow Laboratory for Ocean Science, 180 McKown Point, PO Box 475, West Boothbay Harbor, \\ Maine 04575-0475, USA
}

\begin{abstract}
This study tested the validity of the modified dilution method approach to partition natural phytoplankton mortality into grazer versus virus-induced fractions. A series of experiments was conducted weekly between August and October 2005 from an offshore site in the western English Channel. The phytoplankton community during this period was dominated numerically by Synechococcus spp. and picoeukaryotes. Despite highly significant regression results, no discernible viral lysis of Synechococcus spp. or picoeukaryote populations was apparent during the 3 mo period. Microzooplankton grazing was the major source of mortality for Synechococcus spp. and picoeukaryotes during this time. Statistical analysis indicates that, using our experimental design, the modified dilution approach was not sensitive enough to be able to measure significant viral lysis during the experimental period. Sensitivity analysis indicated that viral mortality occurred at rates of $<0.1 \mathrm{~d}^{-1}$. Methodological impacts on phytoplankton growth rates may also have affected the ability to measure virus-induced mortality of picoeukaryotes, as there was increasing suppression of picoeukaryote growth rate in relation to dilution with the $30 \mathrm{kDa}$ filtrate and a corresponding depression of quantum photosynthetic efficiency $\left(F_{\mathrm{v}} / F_{\mathrm{m}}\right)$ in the $30 \mathrm{kDa}$ dilutions compared to the $0.2 \mu \mathrm{m}$ series. The implications and limitations of the dilution approach for estimating viral versus grazing mortality of natural phytoplankton populations are discussed.
\end{abstract}

KEY WORDS: Viral lysis · Microzooplankton grazing $\cdot$ Dilution $\cdot$ Synechococcus $\cdot$ Picoeukaryotes · Western English Channel · Methodological limitations

\section{INTRODUCTION}

The fate of primary production has important implications for the ecology of, and biogeochemical cycling in, microbial food webs. When phytoplankton cells are grazed, energy is made available to higher trophic levels, whereas virus-mediated mortality forces the food web towards a more regenerative system and dissolved organic matter (DOM) recycling occurs, stimulating bacterial production (Fuhrman 1999, Wilhelm \& Suttle 1999, Brussaard 2004a). The concept that viruses can be a significant mortality agent of marine phytoplankton has been well established over the past 15 yr (e.g. Suttle 2000, Brussaard 2004a). However, the importance of viral mortality of phytoplankton in relation to other loss factors such as grazing is less clear. Although viruses have been shown to significantly reduce primary production (Suttle et al. 1990, Suttle 1992) and cause the decline of algal populations (Bratbak et al. 1993, Nagasaki et al. 1994, Brussaard et al. 1996, Castberg et al. 2001, Jacquet et al. 2002, Wilson et al. 2002), directly measured rates of viral mortality in natural algal populations are not readily available because of the lack of appropriate methods. Thus, for 
most natural phytoplankton communities, the influencing factors that determine whether grazers or viruses dominate and have the most significant impact on the decline of primary production are still virtually unknown. Most studies that have previously examined the impact of grazing versus viral lysis have focused on bacterial populations (Fuhrman \& Noble 1995, Weinbauer \& Peduzzi 1995, Steward et al. 1996, Weinbauer \& Hofle 1998, Guixa-Boixereu et al. 1999, Tuomi \& Kuuppo 1999, Pedros-Alio et al. 2000, Jacquet et al. 2005, Fischer et al. 2006, Wells \& Deming 2006). These studies have shown that both viral lysis and grazing can cause significant mortality, but that the impact of each varies with season, host organism, or environmental conditions. Methods developed for bacterial studies have also been applied to estimate the impact of viruses on phytoplankton populations (e.g. Proctor \& Fuhrman 1990, Jacquet et al. 2002). These studies have shown that virus-induced mortality can be responsible for 6 to $100 \%$ of total phytoplankton mortality. However, most of the studies investigating the role of phytoplankton viruses have been conducted in conditions of high biomass and/or dominance by a single species.

The modified dilution approach (Evans et al. 2003) was introduced to provide a direct measurement of virus-induced mortality of specific phytoplankton. This method is based on the original dilution technique developed by Landry \& Hassett (1982), which has been used extensively to provide estimates of phytoplankton growth and microzooplankton grazing (e.g. Gallegos 1989, Landry et al. 1995, Worden \& Binder 2003). The modified approach includes an additional dilution step created by combining whole seawater with virus-free filtrate in different proportions, to create a gradient of both viral and host abundance, thus allowing the direct measurement of grazer- versus virus-induced mortality. The original dilution approach is based on 3 fundamental assumptions: (1) phytoplankton growth rate is not affected by dilution, (2) grazing mortality is linear with respect to phytoplankton concentration, and (3) phytoplankton growth is exponential (Landry \& Hassett 1982). These assumptions are effectively the same in the modified protocol; however, the appropriateness of this has not been tested. The hypotheses that phytoplankton growth rate is not affected by dilution with viral-free diluent and that phytoplankton growth is exponential during the incubation period were not examined in the original paper by Evans et al. (2003). Changes in phytoplankton physiological condition due to experimental conditions may affect both grazing efficiency or rate (Flynn et al. 1996) and viral infection rates (Van Etten et al. 1991, Bratbak et al. 1998) between dilutions, thus creating inflated/depressed apparent phytoplankton growth rates. Accurate mea- surements of apparent growth rates are fundamental to the dilution approach; thus, violation of these assumptions could provide spurious viral lysis/microzooplankton grazing rates or non-significant linear regressions. The assumption that viral mortality is linear with respect to phytoplankton and/or viral concentration has also not been fully tested. Baudoux et al. (2006) found that for a cultured virus-host model system, losses were linearly proportional to dilution of the viruses. However, this has not been demonstrated for natural communities for which the factors affecting virus-host interactions may be more complicated.

The modified dilution approach was developed during a mesocosm experiment in which Micromonas spp. were the dominant phytoplankton species (Evans et al. 2003). At present, this approach has only been tested under conditions of high phytoplankton abundance (Baudoux et al. 2006) and has not yet been applied to natural non-blooming communities where host and virus densities may be much lower. Therefore, the utility of this technique for estimating viral lysis rates in natural phytoplankton communities is not absolute and needs further testing.

Here, we assess the use of the modified dilution approach to estimate grazing and viral mortality of natural coastal picophytoplankton populations. We investigate the effects of dilution and incubation on phytoplankton host growth rate and photophysiological efficiency and discuss the implications for the outcome of dilution experiments and incubation experiments in general. We also consider the importance of examining taxon-specific grazing/viral lysis and suggest improvements for the use of this method in natural waters. Finally, we introduce a method to illustrate/test the detection limits of the dilution approach.

\section{MATERIALS AND METHODS}

Dilution experiments. The dilution experiments were carried out between 2 August and 17 October 2005, using water collected from Stn L4, a site 10 miles offshore of Plymouth, in the western English Channel $\left(50^{\circ} 15^{\prime} \mathrm{N}, 04^{\circ} 13^{\prime} \mathrm{W}\right)$. Seawater sampling was conducted at the same time of day (10.00 to $11.00 \mathrm{~h}$ ) throughout the experimental period. To prevent contamination of seawater by handling, vinyl gloves were worn throughout water collection and the experimental set up. Seawater from $10 \mathrm{~m}$ depth (30 l) was collected using a 101 Niskin bottle and gently siphoned into clean, light-proof, $10 \mathrm{l}$ polypropylene carboys. To create mesoplankton-free whole water for experiments, the seawater was gently siphoned through $200 \mu \mathrm{m}$ mesh. Carboys were stored in cool boxes, cooled with a flow-through system of surface seawater, 
and remained on board for $1 \mathrm{~h}$ before set-up back at the laboratory.

Experiments were set up according to the protocol of the modified dilution method by Evans et al. (2003) in a temperature-controlled room $\left(15^{\circ} \mathrm{C}\right)$. Seawater was gravity filtered through $0.2 \mu \mathrm{m}$ filters (PALL Acropak Supor membrane capsules) into a clean carboy. After gravity filtration, half of the $0.2 \mu \mathrm{m}$ diluent was passed through a $30 \mathrm{kDa}$ tangential flow filtration system (Pall Omega PES membrane) to create the virus-free diluent. These $0.2 \mu \mathrm{m}$ and $30 \mathrm{kDa}$ diluents were then added to 21 polycarbonate bottles in the correct proportions to create the parallel $t_{0}$ dilution series, i.e. 20 , 40, 70 and $100 \%$ whole water (or 50, 70, 90 and $100 \%$ in experiments conducted on 3,10 and 17 October). Whole water was then gently added by siphoning. The fraction of whole water used in the incubations was changed in the later experiments because phytoplankton abundance decreased and the shape of the regression analyses from the earlier dilutions suggested that the grazing/viral impact was not evident at the most dilute levels. From each $t_{0}$ carboy, triplicate $500 \mathrm{ml}$ polycarbonate bottles were gently filled by siphoning, and placed randomly into temperature-controlled (15 to $16^{\circ} \mathrm{C}$, to match in situ temperatures at $10 \mathrm{~m}$ ), outdoor incubators, with neutral density screening and Perspex covering to match natural light levels at $10 \mathrm{~m}$.

Prior to each experiment, $0.2 \mu \mathrm{m}$ filters, silicon tubing, carboys and incubation bottles were acid-washed in $5 \% \mathrm{HCl}(30 \mathrm{kDa}$ filter cleaned with $1 \% \mathrm{HCl})$ and rinsed thoroughly with Milli-Q water and then filtered seawater. The $0.2 \mu \mathrm{m}$ and $30 \mathrm{kDa}$ systems had $10 \mathrm{l}$ of Milli-Q water flushed through before filtering seawater; the first $5 \mathrm{l}$ of both $0.2 \mu \mathrm{m}$ and $30 \mathrm{kDa}$ filtrates was discarded. Triplicate sub-samples were taken from the $21 t_{0}$ bottles for determination of phytoplankton composition and abundance, virus abundance, and for photophysiological assessment of phytoplankton. Final time point samples were also taken from every bottle at the end of the experimental period, $t_{24}$.

Phytoplankton abundance. Initial $\left(t_{0}\right)$ and final $\left(t_{24}\right)$ phytoplankton composition and abundance estimates were determined by analysis of fresh samples on a FACSort flow cytometer (Becton Dickinson) equipped with a $15 \mathrm{~mW}$ laser exciting at $488 \mathrm{~nm}$ and with a standard filter set up. Samples were analysed at high flow rate $\left(\sim 150 \mu \mathrm{l} \mathrm{min}{ }^{-1}\right)$, and specific phytoplankton groups were discriminated by differences in side scatter and red/orange fluorescence. Flow rates of the flow cytometer were calibrated daily using quality-control beads $(0.5 \mu \mathrm{m}$, Polysciences) of a known concentration. Counts of $>500$ cells were conducted to obtain estimates of phytoplankton abundance of high enough precision ( $\leq 5 \% \mathrm{SE})$, requiring approximately $10 \mathrm{~min}$ sample runs for the most dilute incubations. Files were analysed using WinMDI 2.8 software (Joseph Trotter, http://facs.scripps.edu).

Virus abundance. Virus abundance was determined using the flow cytometric protocol of Brussaard (2004b). At $t_{0}$, samples for viral analysis were fixed with glutaraldehyde $(0.5 \%$ final concentration $)$ for $30 \mathrm{~min}$ at $4^{\circ} \mathrm{C}$, snap frozen in liquid nitrogen and stored at $-80^{\circ} \mathrm{C}$. Samples were subsequently defrosted at room temperature and diluted 100-fold with TE buffer (10 mM Tris-HCl pH 8, 1 mM EDTA, 50 kDa filtered, then autoclaved), stained with SYBR Green 1 at a final dilution of $5 \times 10^{-5}$ of the commercial stock, incubated at $80^{\circ} \mathrm{C}$ for $10 \mathrm{~min}$ in the dark, then allowed to cool for 5 min before analysis using a FACSort flow cytometer (Becton Dickinson) equipped with a $15 \mathrm{~mW}$ laser exciting at $488 \mathrm{~nm}$ with a standard filter set up. Samples were analysed for $2 \mathrm{~min}$ at a flow rate of

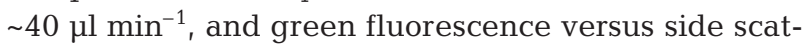
ter were the parameters used to discriminate different virus groups (see 'Results'). Data files were analysed using WinMDI 2.8 software (see above).

Phytoplankton photophysiology. To test the assumption that dilution and experimental incubation do not affect specific phytoplankton photophysiology, samples were taken from the parallel dilution series for assessment of phytoplankton community photosynthetic parameters using fast repetition rate fluorometry (FRRF). The principles of the FRRF fluorescence method are described in Kolber et al. (1998). FRRF was used to determine initial fluorescence $\left(F_{0}\right)$ and the ratio of variable to maximum fluorescence $\left(F_{\mathrm{v}} / F_{\mathrm{m}}\right.$, where $F_{\mathrm{m}}$ is the maximum excitable fluorescence and $F_{\mathrm{v}}$ is $F_{\mathrm{m}}-$ $F_{0}$ ) in a dark-adapted state, as well as the functional absorption cross section of PSII (Photosystem II), $\sigma_{\text {PSII }}$ (the product of the light-harvesting capability of the light-harvesting pigments and the efficiency of excitation transfer to the reaction centre; Kolber \& Falkowski 1993). The $F_{\mathrm{v}} / F_{\mathrm{m}}$ ratio has become an important and easily measurable parameter of the physiological state of the photosynthetic apparatus of plants (Krause \& Weis 1991) and phytoplankton (Yakovleva \& Hidaka 2004), and changes in $F_{\mathrm{v}} / F_{\mathrm{m}}$ and $\sigma_{\text {PSII }}$ can indicate physiological stress in phytoplankton (Geider \& La Roche 1994, Timmermans et al. 2001). Changes in $F_{\mathrm{v}} / F_{\mathrm{m}}$ or $\sigma_{\mathrm{PSII}}$ as a result of experimental stress were tested during dilution experiments conducted on 3, 10 and 17 October at $t_{0}$ and $t_{24}$. Sub-samples were removed from the dilution bottles and dark-acclimated at $16^{\circ} \mathrm{C}$ for $30 \mathrm{~min}$ prior to analysis. Only the dark chamber was activated, and analysis was conducted in darkness to prevent any light interference. Fluorescence was measured using a Chelsea Instruments FAST ${ }^{\text {tracker }}$ (Chelsea Instruments). The FRRF was employed with an acquisition sequence of 100 subsaturating 'flashlets', 20 relaxation flashes and $10 \mathrm{~ms}$ 
sleep time between acquisitions; the flash duration was set to $1.34 \mu \mathrm{s}$. The FRRF was set to auto-gain, and 50 acquisitions sample ${ }^{-1}$ were collected; the first 10 acquisitions from each analysis were discarded. Files were analysed using FRS software $(1.8,1999$, Chelsea Instruments).

Data analysis. Apparent phytoplankton growth rates at each dilution within an experimental series (i.e. $0.2 \mu \mathrm{m}$ and $30 \mathrm{kDa})$ were calculated as $\ln \left(P_{t} / P_{0}\right) / t_{\text {, }}$ where $P_{t}$ and $P_{0}$ are the final and initial measured phytoplankton abundance, respectively, and $t$ is the duration of the experiment $(24 \mathrm{~h})$. We determined if the desired level of dilution was achieved by comparing with analytical flow cytometry the initial abundance estimates of Synechococcus spp. from the diluted $t_{0}$ samples to those from undiluted whole water. Model 1 linear regression analysis of apparent growth rates against the whole water fraction was applied to each of the dilution experimental series $(0.2$ and $30 \mathrm{kDa})$ to estimate instantaneous growth and mortality due to grazing and/or viral lysis. Experiments that produced significant regression slopes for both the $0.2 \mu \mathrm{m}$ and $30 \mathrm{kDa}$ dilution series were further analysed using an F-test (Sokal \& Rohlf 1995) to investigate whether there was a significant difference between the mortality slopes and, therefore, assess the magnitude of viral mortality.

Testing dilution approach sensitivity. To assess the sensitivity of the modified dilution approach to quantify viral mortality, we used the method of Bayne et al. (1981). This approach considers the power of the regression analyses to accurately detect differences between net growth rates in the $0.2 \mu \mathrm{m}$ and $30 \mathrm{kDa}$ dilution series. As significance at the 0.05 level was not achieved for any of the $F$-tests for differences between the $0.2 \mu \mathrm{m}$ and $30 \mathrm{kDa}$ mortality slopes, this raised the question of power or its complement, the probability of Type II error, that is, the probability of failing to detect a real difference (Somerfield \& Clarke 1997). When comparing 2 regression slopes to test for a difference in the mean of the rate measurement $(y)$, this method allows you to determine the number (n) of observations of $y$ (net growth rate in the present study) that should be taken from each dilution series to be able to detect a significant result and estimate a posteriori the power of the statistical analyses ( $F$-tests).

In the present study, when the regression lines for the 2 populations (i.e. the $0.2 \mu \mathrm{m}$ and $30 \mathrm{kDa}$ dilutions) were not assumed to have a common mortality slope, equality of mean apparent phytoplankton growth rate values was examined at a specific size $x_{0}$, which involves a test of the null hypothesis $\left(\alpha_{2}+\beta_{2} x_{0}\right)-\left(\alpha_{1}+\right.$ $\left.\beta_{1} x_{0}\right)=0$, where $\alpha_{1}, \beta_{1}, \alpha_{2}$ and $\beta_{2}$ are the gross growth rates and mortality slopes from Population $1(0.2 \mu \mathrm{m})$ and $2(30 \mathrm{kDa})$ regressions and $x_{0}$ is the point on the $x^{-}$ axis (fraction of whole water) where we estimate the power [(mean $x_{1}+$ mean $\left.\left.x_{2}\right) / 2\right]$. By conducting the above test at a fixed significance level $\mathrm{p}=0.05$ (Type I error; this is implicit in the test), the number (n) of observations of apparent growth rate that would have been required from each population is determined by the power of the test.

The power of the test is defined as the probability of rejecting the null hypothesis (of no difference between the population rates) when it is false, i.e. when the true difference between the mean $y$-values (or intercepts) is $\Delta \alpha$ (specified mean difference). Power is a function of $n$, $p, \Delta \alpha, \sigma^{2}$ and $k$, where $\sigma^{2}$ is the usual 'error' variance about the mean $y$-values (or regression lines), assumed constant over all observations from both populations, and $k$ reflects expected differences in $x$-axis values (Bayne et al. 1991). We applied this method to each pair of regressions from the dilution experiments to assess the power of the $F$-tests to detect changes between the $0.2 \mu \mathrm{m}$ and $30 \mathrm{kDa}$ dilution series.

\section{RESULTS}

\section{Phytoplankton community composition and viral abundance}

During the experimental sampling period (2 August to 17 October) the phytoplankton community enumerated by analytical flow cytometry was dominated by Synechococcus spp. and picoeukaryotes. Nanophytoplankton populations were also present, but in such low abundances that statistically viable counts of cells at the $20 \%$ dilution level were unobtainable for all experiments except the first $\left(2.2 \times 10^{3}\right.$ cells ml $^{-1}$, 2 August). Therefore, dilution experiments were based on changes in Synechococcus spp. and picoeukaryotes only. Abundance of Synechococcus spp. varied between August and October, with a minimum of $5.4 \times$ $10^{3}$ cells ml ${ }^{-1}$ at the end of September and a maximum of $6.8 \times 10^{4}$ cells ml ${ }^{-1}$ at the beginning of August (Table 1). Picoeukaryote abundance however, peaked at the end of August $\left(3.19 \times 10^{4} \mathrm{cells} \mathrm{ml}^{-1}\right)$, with lowest numbers at the beginning of August $\left(1.6 \times 10^{3}\right.$ cells $\mathrm{ml}^{-1}$ ) (Table 1). Virus-like particles were observed and enumerated using AFC (Fig. 1). Viral Group 1 (VLP Pop 1) was present at concentrations of $\sim 1.5 \times 10^{6} \mathrm{ml}^{-1}$ and had higher green fluorescence than Group 2 (other viruses).

\section{Dilution experiments}

The effectiveness of the modified dilution technique is dependent on the efficiency of the $0.2 \mu \mathrm{m}$ filtration 


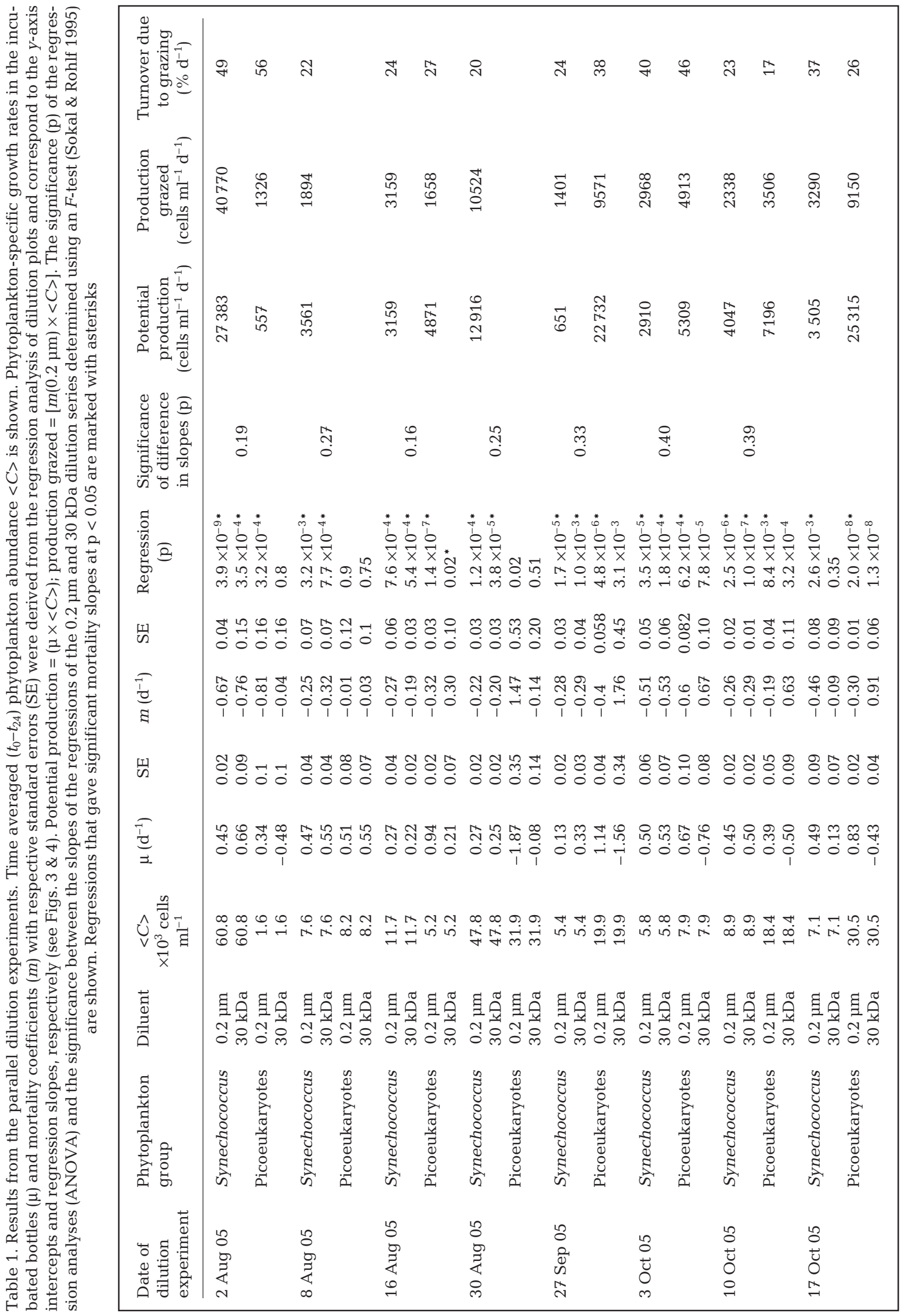




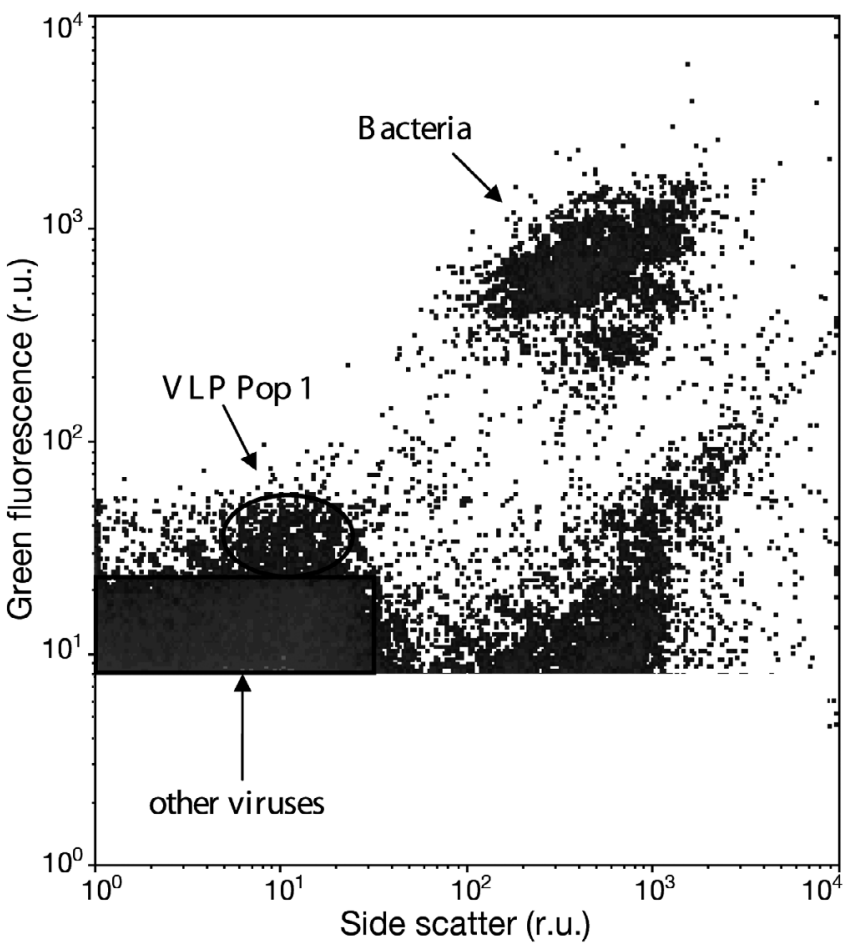

Fig. 1. Typical flow cytometric signature of the virus-like particle populations (VLP) present in natural seawater from L4 during the experimental time period. VLP Pop 1: Viral Group 1; r.u.: relative units

step to create a gradient of grazing pressure and the $30 \mathrm{kDa}$ filtration step to remove viruses from the $0.2 \mu \mathrm{m}$ filtrate, thus creating an additional viral gradient. AFC analysis of VLP Pop $1 \mathrm{ml}^{-1}$ versus the whole water fraction showed that there was no difference in VLP abundance between the levels of dilution in the 0.2 series, and thus the $0.2 \mu \mathrm{m}$ filter allowed the VLPs to pass through freely (Fig. 2). Analysis of the parallel

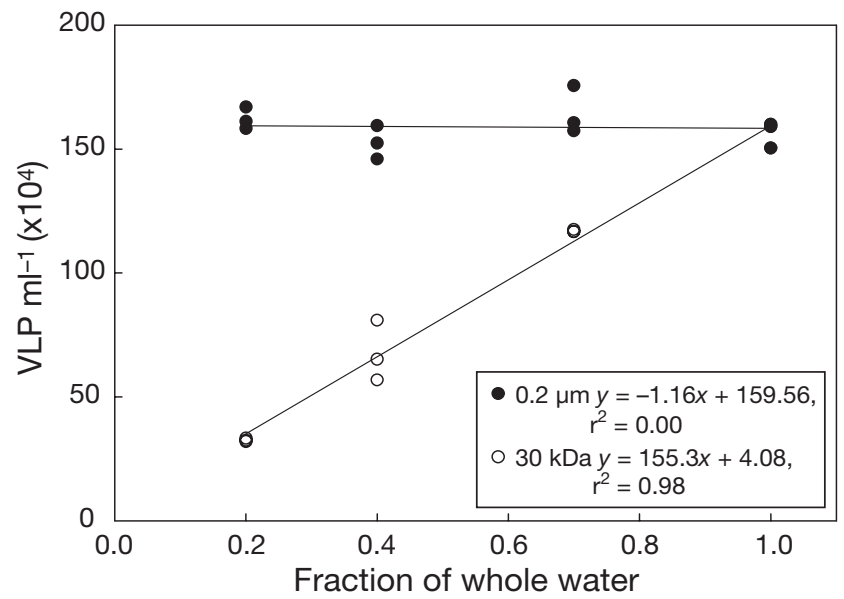

Fig. 2. Abundance of virus-like particles Pop 1 versus the whole water fraction from the parallel dilution experiment set up with $0.2 \mu \mathrm{m}$ and $30 \mathrm{kDa}$ diluent series, conducted on 2 August 2005
$30 \mathrm{kDa}$ series demonstrated that the additional filtration step effectively removed VLPs and produced a gradient of viral abundance within the dilutions (Fig. 2).

Model 1 regression analysis was applied to the dilution experiments and allowed us to determine both the specific growth $(\mu)$ and mortality coefficient $(m)$ in each of the parallel dilution series. For 7 of the 8 experiments, there was a highly significant relationship ( $\mathrm{p} \leq$ 0.01) between Synechococcus spp. apparent growth rate and the level of dilution in both the $0.2 \mu \mathrm{m}$ and 30 kDa series (Fig. 3, Table 1). Synechococcus spp. specific growth rates derived from the standard $(0.2 \mu \mathrm{m})$ dilution series varied during the experimental period from 0.13 to $0.50 \mathrm{~d}^{-1}$ (Table 1) (representing 0.19 to 0.72 divisions $\mathrm{d}^{-1}$, respectively), with highest rates observed in August and October. Rates of Synechococcus spp. mortality due to microzooplankton grazing $(m)$, determined from the standard $0.2 \mu \mathrm{m}$ dilution series, varied from 0.22 to $0.67 \mathrm{~d}^{-1}$ (Table 1), representing a turnover of the Synechococcus spp. populations of 20 to $49 \% \mathrm{~d}^{-1}$, with maximum grazing and turnover occurring at the beginning of August. Grazing by the microzooplankton exceeded the growth of Synechococcus spp. in 4 of the 8 experiments, with grazing mortality equal to or exceeding $100 \%$ of the potential Synechococcus spp. production (Table 1). In 5 out of the 8 dilution experiments viruses appeared to reduce apparent Synechococcus spp. growth rates in the $0.2 \mu \mathrm{m}$ series compared to the $30 \mathrm{kDa}$ incubations (Fig. 3). However, there was no significant difference (F-test; Sokal \& Rohlf 1995) between the regression slopes of apparent growth rate and level of dilution of the $0.2 \mu \mathrm{m}$ and $30 \mathrm{kDa}$ dilution series in any of the experiments $(p \geq 0.1$; Table 1$)$. Therefore, although differences in net growth rate occurred between the dilution series during 5 of the 8 experiments, an estimate of viral mortality of Synechococcus spp. at a level of significance of $\mathrm{p}<$ 0.05 could not be determined from these experiments.

Picoeukaryote-specific growth rates $(\mu)$ calculated from the $0.2 \mu \mathrm{m}$ dilution series were generally higher than those of Synechococcus spp. (excluding the negative growth rate observed on 30 August) and ranged between 0.34 and $1.14 \mathrm{~d}^{-1}$ (representing 0.56 and 1.64 divisions $\mathrm{d}^{-1}$, respectively), with maximum rates reached at the end of September (Fig. 4, Table 1) and minimum growth at the beginning of August. There was a significant relationship between picoeukaryote apparent growth rate and level of dilution in the $0.2 \mu \mathrm{m}$ series in 6 out of the 8 experiments (Table 1). Grazing rates varied from 0.19 to $0.81 \mathrm{~d}^{-1}$, with the microzooplankton consuming between 17 and $56 \% \mathrm{~d}^{-1}$ of the picoeukaryote community (Table 1). However, picoeukaryote growth exceeded grazing by the microzooplankton in all experiments apart from the experiment 

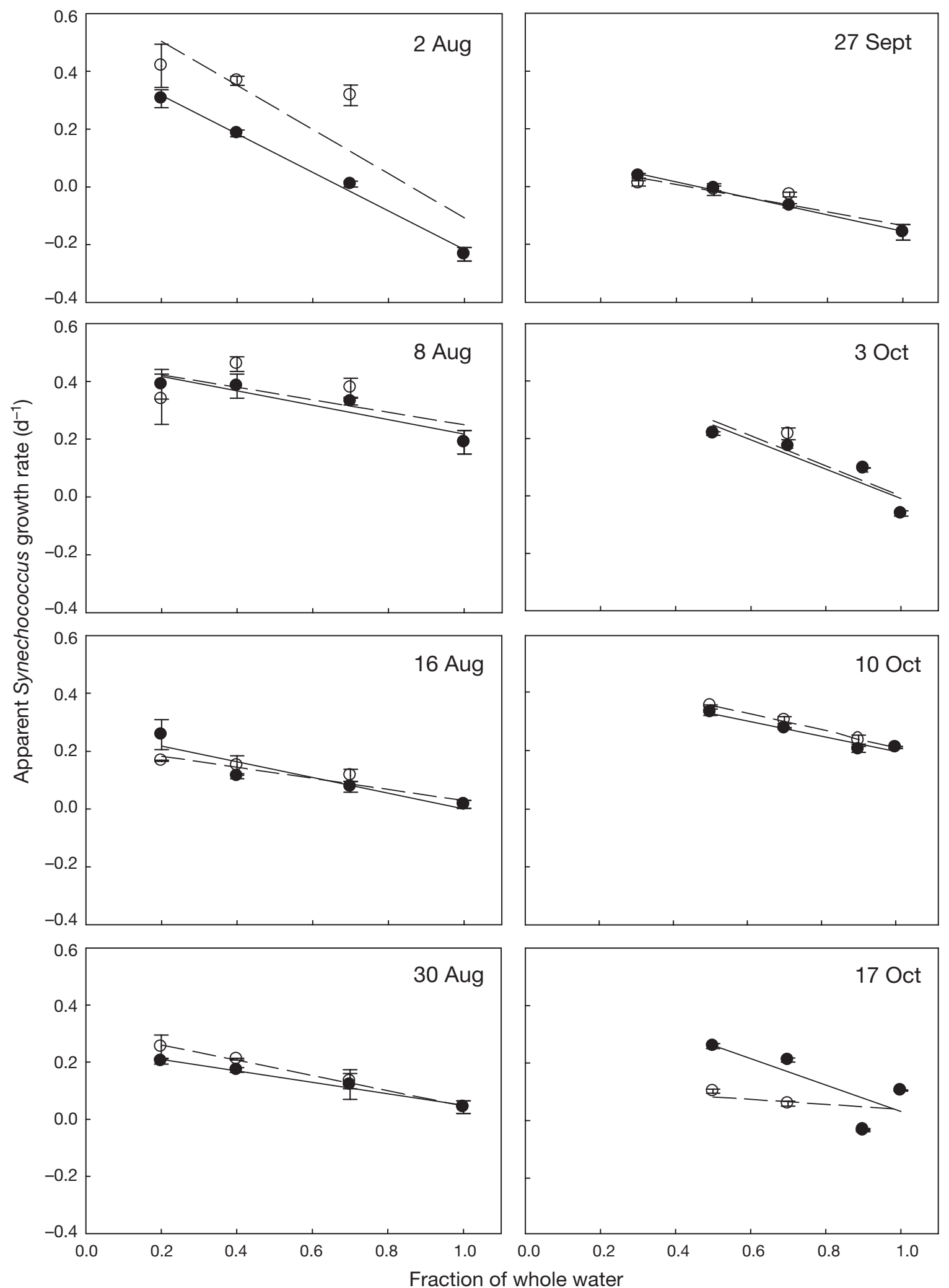

Fig. 3. Dilution plots of apparent Synechococcus spp. growth rate $\left(\mathrm{d}^{-1}\right)$ versus the whole water fraction in the parallel experiments conducted from August to October 2005. Closed and open circles represent growth rates from the $0.2 \mu \mathrm{m}$ and $30 \mathrm{kDa}$ dilution series, respectively. Error bars represent $1 \mathrm{SD}$. Solid and dashed lines represent linear regressions of data from the $0.2 \mu \mathrm{m}$ and $30 \mathrm{kDa}$ dilution series, respectively. See Table 1 for Model 1 regression equations and statistical significance 


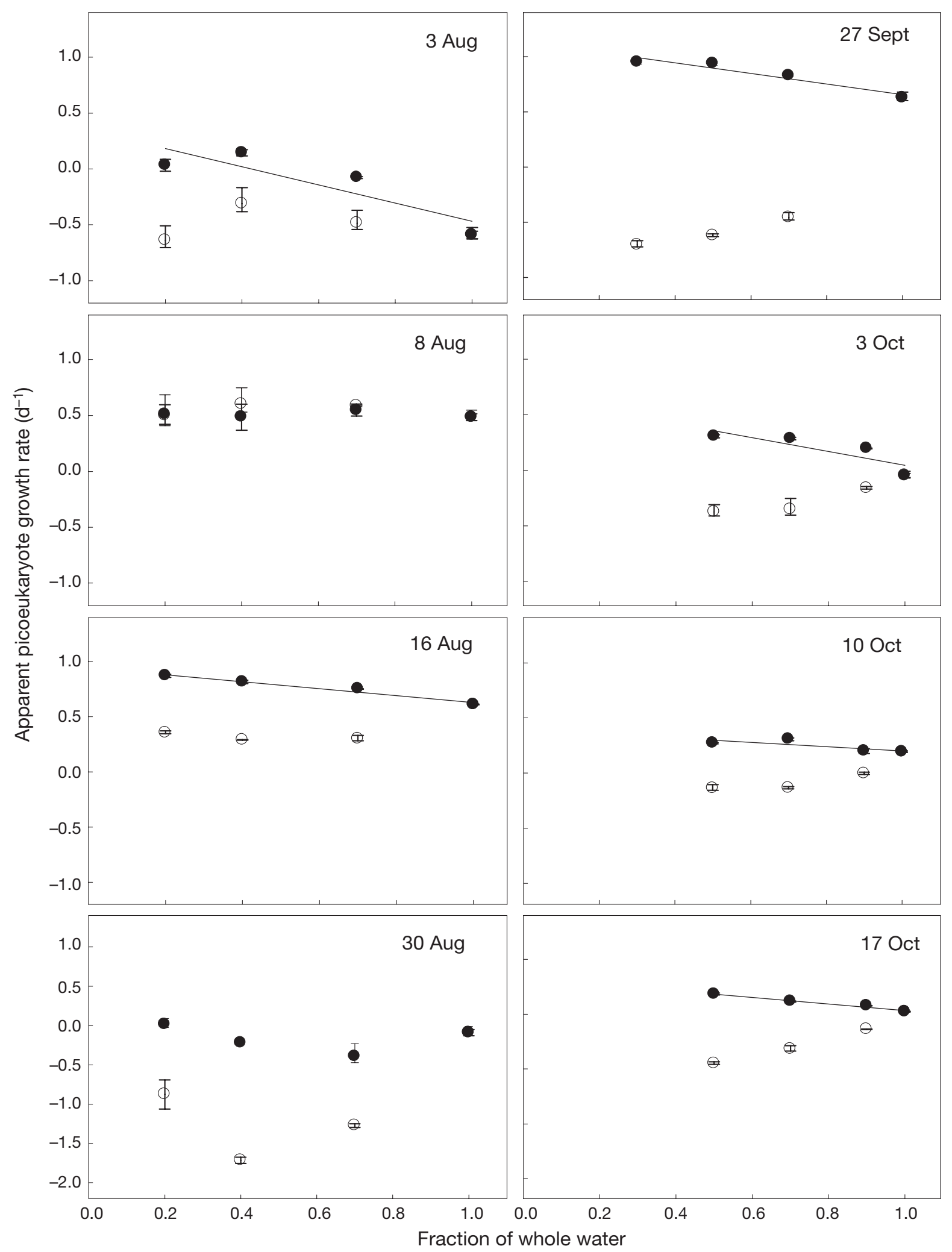

Fig. 4. Dilution plots of apparent picoeukaryote growth rate $\left(\mathrm{d}^{-1}\right)$ versus the whole water fraction in the parallel experiments conducted from August to October 2005 (note different scale for $y$-axis on 30 August). Closed and open circles represent growth rates from the $0.2 \mu \mathrm{m}$ and $30 \mathrm{kDa}$ dilution series, respectively. Error bars represent $1 \mathrm{SD}$. Solid lines represent linear regressions of data from the $0.2 \mu \mathrm{m}$ dilution series. See Table 1 for Model 1 regression equations and statistical significance 
conducted on 2 August, when growth rates and picoeukaryote abundance were minimal. In contrast to the $0.2 \mu \mathrm{m}$ series and to the situation for Synechococcus spp., no significant regressions were obtained for picoeukaryotes for the $30 \mathrm{kDa}$ series. Creating a gradient of grazing and viral pressure in the $30 \mathrm{kDa}$ dilution series did not provide a significant relationship between picoeukaryote apparent growth rate and level of dilution for any of the experiments (Fig. 4). Furthermore, there appeared to be an increasing suppression of growth rate relating to increased dilution with the $30 \mathrm{kDa}$ diluent, which was reflected in the phytoplankton community photosynthetic parameters.

Photophysiological assessment of the phytoplankton community during experimental incubation revealed that, although phytoplankton fluorescence parameters in the dilution samples were the same for both the $0.2 \mu \mathrm{m}$ and $30 \mathrm{kDa}$ series at $t_{0}$ ( $t$-test, $\left.\mathrm{p}>0.05\right)$, by $t_{24}$, both $F_{\mathrm{v}} / F_{\mathrm{m}}$ and $\sigma_{\mathrm{PSII}}$ were significantly lower in the $30 \mathrm{kDa}$ samples $(t$-test, $\mathrm{p}<0.05)$. This significant decrease in photophysiology was observed during the dilutions occurring on 3,10 and 17 October (results of experiment on 10 October are shown in Fig. 5), and the

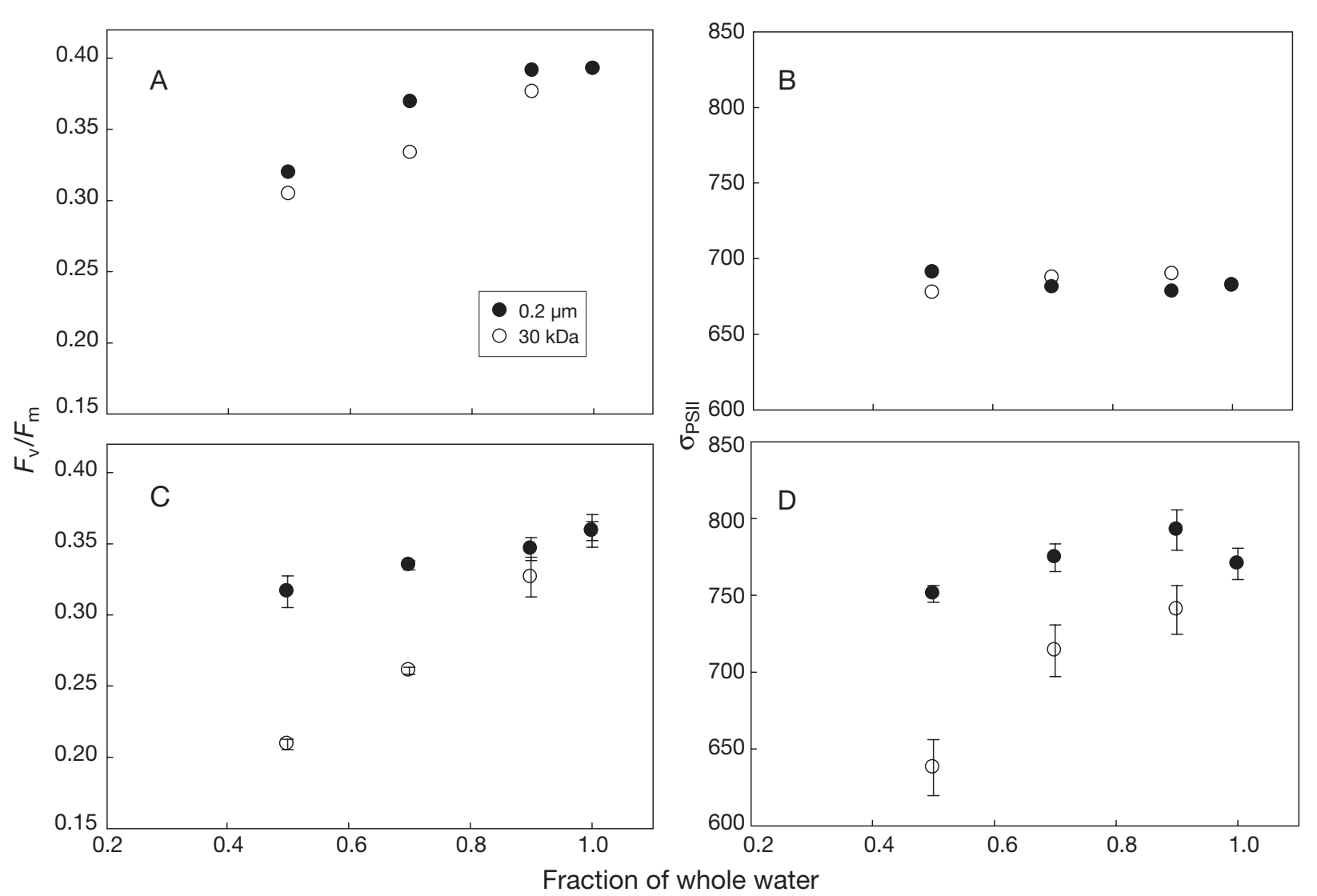

greatest difference between the $0.2 \mu \mathrm{m}$ and $30 \mathrm{kDa}$ dilution series was in the most dilute samples (50 or $70 \%$ whole water). However, there was no apparent suppression of Synechococcus spp. net growth rates (Fig. 3), suggesting that taxon-specific physiological differences may be important for the outcome of dilution experiments.

\section{Sensitivity of dilution methodology}

Detection of significant viral mortality from natural populations was not possible during the present study using the modified dilution approach. Based on the experimental design utilised in this study, i.e. 4 dilutions and 12 samples in total (3 replicates at each dilution level), the method of Bayne et al. (1981) allowed an examination of the power to detect differences in Synechococcus spp. mortality between the $0.2 \mu \mathrm{m}$ and $30 \mathrm{kDa}$ slopes (Table 2). For a specified mean difference in mortality between the slopes $(\Delta \alpha)$, the scaled difference $(\Delta \alpha / k \sigma)$ was first calculated and then the power of the regression analyses to detect the speci-

Fig. 5. Photophysiological parameters $F_{\mathrm{v}} / F_{\mathrm{m}}$ and $\sigma_{\mathrm{PSII}}$ versus the whole water fraction from the parallel dilution series conducted on 10 October 2005. (A,B) Data are derived from analysis of samples at $t_{0}$ and are single estimates; $(\mathrm{C}, \mathrm{D})$ data are from $t_{24}$ and are triplicate measurements with $1 \mathrm{SD}$ 
Table 2. Power (p) of $F$-tests to detect a difference between the Synechococcus spp. $0.2 \mu \mathrm{m}$ and $30 \mathrm{kDa}$ regression slopes from parallel dilution experiments conducted from August to October 2005. $\Delta \alpha$ : the specified mean difference to be detected between the mortality slopes; $\Delta \alpha / k \sigma$ : the scaled difference between the slopes (error term associated with the variance about the $x$ and $y$ variables in the $0.2 \mu \mathrm{m}$ and $30 \mathrm{kDa}$ dilution series regression analyses, see Bayne et al. 1981)

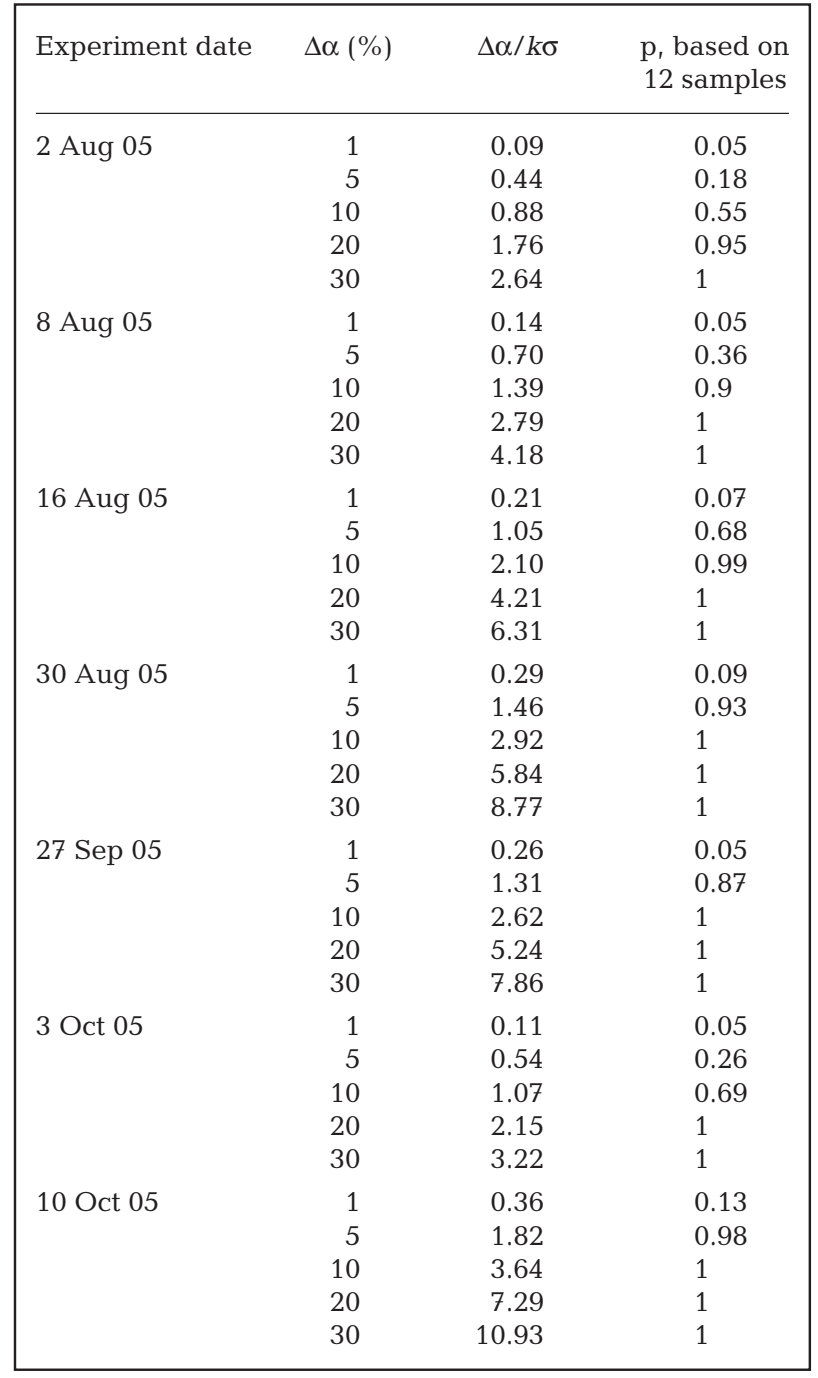

fied difference was determined from the power curves of Bayne et al. (1981). Thus, to detect a $5 \%$ difference between the $0.2 \mu \mathrm{m}$ and $30 \mathrm{kDa}$ mortality slopes for the dilution experiment conducted on 2 August, the current experimental design would provide a test with a power of only 0.18 (Table 2). Whereas, if the mean difference to be detected was $20 \%$, the current sample size of 12 would provide a test with a power of 0.95 . Results indicate that apart from Experiments 1 and 6 (2 August and 3 October), the F-tests would have had significant power to detect differences as low as $10 \%$ in mortality slopes. For dilution Experiment 1 (2 August), the difference between the grazing and viral mortality regressions would have had to be at least $20 \%$ to detect a difference using $F$-test analysis (Table 2). Thus, the conclusion is that there was a difference in mortality of $<10 \%$ between the $0.2 \mu \mathrm{m}$ and $30 \mathrm{kDa}$ regression slopes for most of the experimental period, and, therefore, the viral mortality rate must have been $<0.1 \mathrm{~d}^{-1}$ during this time.

\section{DISCUSSION}

\section{Synechococcus spp. and picoeukaryote growth and grazing dynamics}

The present study aimed to determine the temporal change in grazing versus virus-induced mortality of natural phytoplankton populations at a coastal site in the western English Channel. Using the modified dilution technique, we determined that microzooplankton grazing was a significant cause of autotrophic picoplankton mortality at L4 from August to October and that grazing exceeded Synechococcus spp. production for half of the experiments. Grazing exceeded picoeukaryote production only during the first experiment at the beginning of August, but other loss factors such as sedimentation, viral infection, or cell lysis (Kirchman 1999) may have been important sources of mortality. Maximum turnover of Synechococcus spp. and picoeukaryote production due to grazing occurred in August, which corresponds with the timing of increased picoplankton and microzooplankton abundance at the coastal Site L4 (Rodríguez et al. 2000).

Viruses appeared to have a minor impact on Synechococcus populations at L4 during this time period, with virus-induced mortality rates of $<10 \% \mathrm{~d}^{-1}$ estimated using a combination of the modified dilution approach and statistical analysis. Although the presence of viruses in the $0.2 \mu \mathrm{m}$ diluent appeared to suppress apparent phytoplankton growth rates compared to the $30 \mathrm{kDa}$ series, we were not able to quantify significant viral lysis during this study. Whether this is a true reflection of the functioning of the microbial community at L4 during our sampling period or a result of the sensitivity of this method in natural waters has not been fully resolved. However, the experimental design appeared to satisfy the correct protocol for modified dilution incubations (Evans et al. 2003) in that, parallel experiments were conducted, 1 with a gradient of microzooplankton abundance and viral concentration (30 kDa filtrate) and 1 with a gradient of microzooplankton abundance $(0.2 \mu \mathrm{m}$ filtrate).

For Synechococcus spp. at least, we have demonstrated that viral mortality rates $>10 \% \mathrm{~d}^{-1}$ would need to occur to enable their estimation using the modified dilution approach method at L4. Rodríguez et al. (2000) 
investigated the temporal change in cyanobacteria and free virus-like particle abundance at Stn L4 and suggested that, although the role of viruses was not important from October through the winter period, there was an elevation of viral biomass in August that corresponded with an increase in cyanobacteria. Evans et al. (2003) estimated that the virus-induced mortality of the picoeukaryote Micromonas spp. standing stock was 9 to $25 \% \mathrm{~d}^{-1}$, and, on $1 \mathrm{~d}$, viral lysis caused the loss of $50 \%$ of the Micromonas spp. production. However, even under the favourable, high-abundance conditions of a mesocosm, significant $(p<0.05)$ viral lysis was only determined in 1 out of the 3 experiments in their study. In natural populations, where abundance is much lower and diversity is much greater, the chances of successfully measuring lysis events using the modified dilution approach may be even smaller.

\section{Lytic cycle duration}

One of the fundamental assumptions of the original Landry and Hassett dilution method (Landry \& Hassett 1982) is that phytoplankton mortality during the incubation period is a result of an encounter between grazer and prey. In the modified dilution approach phytoplankton cells may already be infected at the beginning of the experiment (Jacquet et al. 2005), and, thus, this component of cell lysis would not vary with dilution. The length of the lytic cycle of the virus will dictate whether measurable cell lysis occurs during the incubation period (Evans et al. 2003, Jacquet et al. 2005, Baudoux et al. 2006). Evans et al. (2003) stress that because the length of duration of dilution experiments is typically $24 \mathrm{~h}$ and the timing of the lytic cycle may correspond with that of the host growth rate (Jacquet et al. 2005), the modified dilution method may be most applicable to species with high growth rates. Thus, it is important to tailor the incubation period to the lytic cycle, but this requires a priori knowledge. In the present study, the maximum specific growth rate $(\mu)$ of Synechococcus spp. determined was $0.5 \mathrm{~d}^{-1}$, representing 0.65 divisions $\mathrm{d}^{-1}$. Therefore, as the minimum Synechococcus spp. generation time (determined from dilution experiments) was $1.39 \mathrm{~d}$, this suggests that the experimental incubation period of $24 \mathrm{~h}$ was not sufficient for the latent period of the virus. Thus, infection events that occurred during the $24 \mathrm{~h}$ incubation period may not have resulted in cell lysis. However, even when dilution experiments were run for $48 \mathrm{~h}$ (data not shown), no significant viral lysis could be measured using this method. Picoeukaryote generation times $(\sim 14 \mathrm{~h})$ were much shorter than those of Synechococcus spp.; therefore, in theory, we should have been able to capture a complete infection-lysis cycle within the $24 \mathrm{~h}$ incubation period. However, as picoeukaryote net growth rates and phytoplankton photophysiology appeared to be suppressed in the 30 $\mathrm{kDa}$ dilution series, this reduction in host physiology may have affected the duration of the latent period.

The absence of significant viral mortality rates in this study may have been a result of the absence of viral lysis during this time period. However, host specificity is another factor that should be taken into consideration when interpreting results from these experiments. Although relatively high numbers of viruses were present in the incubated samples, they may not have been specific to the Synechococcus spp. or picoeukaryote populations present in the L4 community at that time. The relatively high host specificity of marine cyanophages suggests that the probability of a successful encounter with a suitable host is likely to be small (Suttle \& Chan 1993). Viruses that infect the picoeukaryote Micromonas spp. have been found to maintain a stable coexistence with their host rather than causing a rapid decline (Cottrell \& Suttle 1995). This may be the situation for the picoeukaryotes at L4, where viruses may act as population-controlling agents rather than bloom terminators. Thus, constant lysis may occur at low rates below the sensitivity of the dilution approach. Without information about host specificity we have no way of knowing whether the relatively high numbers of viruses present were capable of infecting the phytoplankton populations present at L4 during our study.

\section{Precision of apparent growth rate determination}

A key factor for gaining a significant outcome in both the original (Landry \& Hassett 1982) and the modified dilution method (Evans et al. 2003) is the accuracy of the apparent growth rate measurements. Relatively precise estimates of initial and final abundances are needed to minimize the error generated through calculations of population rates of change (Landry 1993). The ability to quantify initial $t_{0}$ and $t_{24}$ parameters of interest such as phytoplankton abundance within acceptable levels of precision (i.e. $<5 \%$ standard error) is fundamental for the success of this approach. This can be particularly challenging when attempting to enumerate taxon-specific abundances in natural populations. Sources of error can occur from imprecise sub-sampling, natural variability between replicates at the same dilution and non-linear grazing/viral lysis responses between dilution levels. Although nonlinear results have been reported previously for standard $0.2 \mu \mathrm{m}$ dilution experiments (e.g. Gallegos 1989, Landry et al. 1993, Lessard \& Murrell 1998), all of the $0.2 \mu \mathrm{m}$ Synechococcus spp. dilutions in this study pro- 
duced significant linear regressions. Linearity in the dilution experiment data was also observed for Synechococcus spp. in the Sargasso Sea (Worden \& Binder 2003). The original dilution protocol was modified (Landry et al. 1995) to include an internal measure of 'relative grazing activity' to improve the accuracy of grazing rate measurements. This internal measure was introduced because of the potential violation of the assumption that grazing impact varies in direct proportion to the dilution of grazer population density. In theory the mechanism of viral infection is simpler than grazing in that a single virus infects only a single host. Therefore, the premise that grazer-prey interactions should follow a linear rather than a non-linear response with dilution should also apply to virus-host encounter and infection too. However, like grazers, viruses and their hosts are not just inert particles and so in reality may not observe simple encounter rate theory. Factors such as threshold host concentrations, host defence mechanisms, or changes in nutrient regeneration caused by virus dilution may cause a deviation from the linear viral lysis model. Whether this hypothesis remains true throughout the experimental period has not yet been tested for virus/host densities to our knowledge, and viral lysis may not be linearly related to dilution factor. This is an important assumption of the modified dilution technique that needs to be clarified.

\section{Sensitivity of regression analysis approach for detecting viral mortality}

Using the Synechococcus spp. dilution data from this study and the method of Bayne et al. (1981), we examined the rigour of our experimental design and resulting data to measure viral lysis of the phytoplankton community at L4. Differences between the dilution experiments in terms of the degree of viral mortality that would have to be occurring to be able to measure a significant lysis rate were not based solely on Synechococcus spp. abundance and apparent growth rate. Results from the analyses showed that virus-induced mortality of Synechococcus spp. at L4 must have been $<0.1 \mathrm{~d}^{-1}$ for the majority of the time during these experiments. This is consistent with a previous study in which viral mortality rate of Synechococcus spp. was estimated to be $\sim 0.05 \mathrm{~d}^{-1}$ (Suttle \& Chan 1994). However, it is a lower rate than has been determined for viral mortality of other phytoplankton species such as Emiliania huxleyi in which lysis can be 25 to $100 \%$ of the net mortality per day (Bratbak et al. 1993, Jacquet et al. 2002) or Phaeocystis spp. with lysis rates reported of between 0.01 and $0.35 \mathrm{~d}^{-1}$ (Baudoux et al. 2006). However, for most of these studies virus-induced mor- tality rates were not measured directly, but were derived from estimates of either the fraction of visibly infected cells or of burst size per cell calculated from the number of virus-like particles released from host cells in TEM images. Both of these methods have a degree of error associated with them (Suttle 2005). Though Baudoux et al. (2006) used the modified dilution approach, it is unclear from their data whether significant differences were found between grazing mortality and grazing \& viral mortality slopes in the dilution experiments. The authors did provide errors around the calculated viral lysis and grazing rate estimates that strongly suggest that at least some of their data were valid, but they did not test the significance between the $0.2 \mu \mathrm{m}$ and $30 \mathrm{kDa}$ slopes (Baudoux et al. 2006). As this is a fundamental requirement of this method, the validity of these viral mortality rates is uncertain. Furthermore, our analysis indicates that significant viral mortality rates of $<0.1 \mathrm{~d}^{-1}$ are unlikely to be detected using the modified dilution approach.

From the present study, the highest rates of viral mortality needed for a measurable significant viral lysis rate using the modified dilution method were found for Experiment 1, which was conducted at the beginning of August when Synechococcus spp. biomass was at its maximum. Based on the results from this study, grazing appears to control the phytoplankton biomass at L4 from August to October, and viral lysis is at a minimum. This theory is supported by the high power of the $F$-tests to detect relatively low levels of viral mortality (i.e. 1 to $5 \%$; Table 2) when grazing rates were low, as in the experiments conducted on 16 and 30 August and on 27 September and 10 October. That significant differences between the $0.2 \mu \mathrm{m}$ and $30 \mathrm{kDa}$ regressions were not obtained during this time period suggests that viral lysis rates must have been $<0.1 \mathrm{~d}^{-1}$.

The ability to determine viral lysis rates using the modified dilution method is reliant on the accuracy of the grazing data from the $0.2 \mu \mathrm{m}$ dilutions and an appropriate sample number in both dilution series to be able to detect a difference between the $0.2 \mu \mathrm{m}$ and $30 \mathrm{kDa}$ regression slopes. Low (natural) levels of viral mortality challenge this method unless it can be modified to include more replicates and better precision. Using the sensitivity test (Bayne et al. 1981) will improve the efficiency of dilution experiments by demonstrating the level of modification that needs to be made to the experimental design, i.e. determining the appropriate sample number for production of significant results. However, this method is also a useful tool to apply to modified dilution experiment results because it determines the level at which the regression analysis and subsequent $F$-tests are powerful enough to be able to detect differences in mortality. Therefore, an understanding can be gained of the 
upper limits of viral mortality that are occurring even when significant lysis rates are not obtained from the regressions. By assessing the sensitivity of the statistical analyses, the method of Bayne et al. (1981) allows the distinction between the rejection of 'failed' experiments because of the real absence of viral mortality in the environment versus rejection because of methodological errors such as a lack of sensitivity or inaccuracies derived during the experimental set up and sample analysis (see 'Precision of apparent growth rate determination'). Consequently, it is an important addition to the standard dilution protocol and should be used in any applications of the Evans et al. (2003) approach to viral mortality. Moreover, the sensitivity test is also applicable for any assessment of dilution-based grazing rates when investigating trends in e.g. selectivity, nutrient limitation, or seasonal changes. Assessing the power of the test when comparing regression slopes between dilution experiments will provide an indication of the accuracy and error associated with the analyses and, thus, provide a more powerful indication of 'real' versus experimentally induced variation.

\section{Viral/host density thresholds}

One of the key assumptions of the original dilution protocol (Landry \& Hassett 1982) is that grazing remains linear with respect to dilution. However, in certain environments microzooplankton grazing may cease below a certain prey concentration because of a prey density threshold, and the resulting dilution regression will become non-linear (Gallegos 1989). The possibility of threshold concentrations also needs to be considered during modified dilution experiments, and the level of abundance of both phytoplankton and grazers/viruses needs to be adjusted to allow a sufficiently high encounter rate even at the lowest level of dilution. In the context of the present study, the linear responses obtained from the dilution series suggest that the Synechococcus spp. density was not diluted below a threshold level. However, to test this, halfway through the study period, we altered our experimental design so that the lowest dilution factor was 0.5 instead of 0.2. Thus, the abundance would not be as diluted and the minimum contact rates between viruses and potential hosts would be increased. However, this did not appear to improve the sensitivity of this method for estimating viral lysis rates at L4. Even by diluting only by $50 \%$ we may have decreased the virus/host encounter rate below the level of detection or we may have reduced host density below an infection threshold concentration. Jacquet et al. (2002) found that there was a threshold Emiliania huxleyi concentration above which virus production was induced. The con- cept of threshold host levels has also been suggested for natural populations of cyanobacteria and cyanophages (Suttle \& Chan 1994, Rodda 1996). This hypothesis was not tested in the present study, but, if threshold concentrations do occur for natural virus populations, this has important implications for the experimental design of modified dilution experiments, in the same way that grazing thresholds are a concern for the original dilution methodology (Landry \& Hassett 1982). The effect of reduced viral mortality because of a host threshold in the dilute treatments could produce a non-linear response and, thus, an under-estimation of the viral lysis rate. Another factor that could change the viral mortality response is the possibility that grazers may preferentially graze virusinfected cells. Preferential grazing was not assessed during this study so it is uncertain whether it actually occurs during dilution experiments and, if so, whether it would cause an under- or over-estimation of viral mortality rates. However, if this phenomenon does occur typically, it will have serious implications for the use of the modified dilution approach to measure viral mortality rates.

\section{Methodological implications for nutrient regeneration}

Removal of viruses from the dilution series by diluting with virus-free filtrate may also be a factor that affects the usefulness of this technique for estimating viral lysis rates in relation to grazing mortality. Although not assessed in this study, because viruses increase nutrient recycling (Wilhelm \& Suttle 1999), by adding virus-free filtrate to the $100 \%$ whole water the nutrient status within the $30 \mathrm{kDa}$ dilution series may be different from that of the $0.2 \mu \mathrm{m}$ system. Thus, during the incubation period, phytoplankton growth rates may be suppressed in the $30 \mathrm{kDa}$ series. Suttle et al. (1996) found that the growth rates of Synechococcus spp. samples from low-nutrient waters of the Gulf of Mexico were lower in incubations that were diluted with virus-free $10 \mathrm{kDa}$ diluent compared to in incubations diluted with $0.2 \mu \mathrm{m}$ diluent (Suttle 2000). The authors suggested that Synechococcus spp. growth was stimulated by enhanced recycling of nutrients due to viral lysis of hosts in seawater containing viruses (0.2 $\mu \mathrm{m}$ diluent) compared to the virus-free water. Decreasing bacteriophage abundance would reduce bacterial lysis, which may affect nutrient regeneration. We also observed a suppression of Synechococcus spp. growth rates in the $30 \mathrm{kDa}$ dilution series compared to the $0.2 \mu \mathrm{m}$ bottles during modified dilution experiments in the oligotrophic North Atlantic (authors' unpubl. data), and this may explain the lack of linear- 
ity at low levels of dilution in the present study. Therefore, this may be a general phenomenon that negates the use of this technique in low-nutrient systems without nutrient amendments. However, further modified dilution studies need to be undertaken in low-nutrient environments before conclusions can be made regarding this point.

In the original dilution protocol (Landry \& Hassett 1982, Landry et al. 1995), nutrient amendment was suggested in nutrient-limited waters to ensure phytoplankton growth rates are independent of the dilution effect. Nutrients were not added to the bottles during the L4 experiments for several reasons: because we did not expect nutrient limitation to be an issue with coastal L4 water during this time period; because we wanted to determine natural growth, grazing and viral lysis rates without the bias of nutrient addition; and because of the potentially negative effects of nutrient addition on microzooplankton abundance (Gifford 1988) and phytoplankton growth (Lessard \& Murrell 1998). As we were able to obtain significant grazing rates for nearly all experiments, we feel that we were justified in not adding nutrients.

Although Synechococcus spp. growth rates may have been elevated in the $30 \mathrm{kDa}$ dilution series, picoeukaryote growth rates appeared to be negatively affected by dilution in the series with the ultra-filtered diluent. Whether this effect is due to a lack of recycling of an essential nutrient for picoeukaryote growth caused by removal of viruses or to the presence of a deleterious compound in the $30 \mathrm{kDa}$ diluent is unclear at present. However, because we were able to measure phytoplankton photophysiological efficiency during the experiments on 3,10 and 17 October using FRRF, we know that at $t_{24}, F_{\mathrm{v}} / F_{\mathrm{m}}$ and $\sigma_{\mathrm{PSII}}$ were significantly lower in the $30 \mathrm{kDa}$ dilution series. This response was not observed in the $0.2 \mu \mathrm{m}$ series and was only observed in the $30 \mathrm{kDa}$ samples at the end of the experimental period $\left(t_{24}\right)$, not at $t_{0}$. Changes in these parameters reflect imbalances in the photochemistry of PSII (Kolber \& Falkowski 1993) and have been associated with physiological stress and, in particular, with nutrient stress (Yentsch et al. 2004); though more recently this link has been debated (Kruskopf \& Flynn 2006). At present, we do not know the exact cause for changes in the efficiency of PSII in the phytoplankton from the $30 \mathrm{kDa}$ series during the dilution experiments; whether this is a typical response and what the causal factors are requires further investigation. However, these results demonstrate that increasing levels of $30 \mathrm{kDa}$ filtrate appeared to have deleterious effects on photosynthetic efficiency of the bulk of the phytoplankton. This corresponds with the suppression of picoeukaryote net growth rate with increasing dilution in the $30 \mathrm{kDa}$ series. Interestingly, the factor decreas- ing picoeukaryote growth rates did not appear to affect Synechococcus spp. However, this does not mean that there was no physiological effect. These results highlight the importance of monitoring various physiological parameters of phytoplankton communities during experimental incubations, particularly when trying to estimate growth and mortality rates from natural waters.

\section{SUMMARY}

By using the modified dilution technique, this study has shown that microzooplankton grazing was the major mortality factor for Synechococcus spp. and picoeukaryote populations at a coastal site in the western English Channel from August to October 2005. Significant viral mortality rates were not determined during this time, but sensitivity analysis suggested that viral mortality occurred at rates of $<0.1 \mathrm{~d}^{-1}$. Such low rates of mortality are difficult to measure using the modified dilution approach in its current format in natural phytoplankton populations, because of the lack of sensitivity and the potential methodological errors associated with this technique. By improving the experimental design through increased sample number, diluting biomass to an appropriate level to allow virus/host encounter even at the lowest level of dilution, assessing taxon-specific mortality rates and combining this approach with methods that assess host/viral diversity and host specificity, this method may be able to provide realistic estimates of viral mortality in natural waters. However, addition of virus-free diluent negatively affected picoeukaryote physiological condition and suppressed growth rates. These effects were not observed for Synechococcus populations. Thus, the taxon-specific physiological effects of this method should also be assessed throughout experimental incubations. Although there are assumptions associated with the modified dilution approach that have not yet been tested and further application of this technique needs to be conducted with natural populations of phytoplankton, at present it is the only method that can potentially derive viral lysis rates from phytoplankton mortality directly. It is also the only single method that can, in theory, provide concurrent estimates of grazing and virus-induced mortality. Though this study has highlighted some limitations of this approach, it has also provided potential improvements that can be included in the experimental design. These improvements include ensuring precision in the measurement of the variables used to determine phytoplankton apparent growth rates. Furthermore, the length of experimental incubation must be constrained to allow enough time for host lysis. Non-standard 
levels of dilution appropriate to abundance levels of natural host/virus populations should be considered. If possible, the photophysiological state of host populations should be assessed during incubation. Finally, the sensitivity of the regression analyses must be determined by assessing the power of the test. Therefore, although the modified dilution approach requires adaptations to suit the environmental conditions being investigated and needs further testing in natural waters, it has the potential to be a useful tool for the partitioning of phytoplankton mortality into grazing and virus-induced fractions.

Acknowledgements. We thank the crew of RV 'Plymouth Quest' for their assistance with sample collection, P. J. Somerfield and K. R. Clarke for statistical advice and the anonymous reviewers for their valuable suggestions on the manuscript. This work was funded by a Natural Environment Research Council (NERC) standard Research Grant NER/A/S/2001/ 01202. The research of S.D.A. and W.H.W. was supported through the NERC-funded core strategic research programme of the Plymouth Marine Laboratory.

\section{LITERATURE CITED}

Baudoux AC, Noordeloos AAM, Veldhuis MJW, Brussaard CPD (2006) Virally induced mortality of Phaeocystis globosa during two spring blooms in temperate coastal waters. Aquat Microb Ecol 44:207-217

Bayne BI, Clarke KR, Moore MN (1981) Some practical considerations in the measurement of pollution effects on bivalve molluscs, and some possible ecological consequences. Aquat Toxicol 1:159-174

Bratbak G, Egge JK, Heldal M (1993) Viral mortality of the marine alga Emiliania huxleyi (Haptophyceae) and termination of algal blooms. Mar Ecol Prog Ser 93:39-48

Bratbak G, Jacobsen A, Heldal M, Nagasaki K, Thingstad F (1998) Virus production in Phaeocystis pouchetii and its relation to host cell growth and nutrition. Aquat Microb Ecol 16:1-9

Brussaard CPD (2004a) Viral control of phytoplankton populations - a review. J Eukaryot Microbiol 51:125-138

Brussaard CPD (2004b) Optimization of procedures for counting viruses by flow cytometry. Appl Environ Microbiol 70: 1506-1513

Brussaard CPD, Kempers RS, Kop AJ, Riegman R, Heldal M (1996) Virus-like particles in a summer bloom of Emiliania huxleyi in the North Sea. Aquat Microb Ecol 10:105-113

Castberg T, Larsen A, Sandaa RA, Brussaard CPD and others (2001) Microbial population dynamics and diversity during a bloom of the marine coccolithophorid Emiliania huxleyi (Haptophyta). Mar Ecol Prog Ser 221:39-46

Cottrell MT, Suttle CA (1995) Dynamics of a lytic virus infecting the photosynthetic marine picoflagellate Micromonas pusilla. Limnol Oceanogr 40:730-739

Evans C, Archer SD, Jacquet S, Wilson WH (2003) Direct estimates of the contribution of viral lysis and microzooplankton grazing to the decline of a Micromonas spp. population. Aquat Microb Ecol 30:207-219

Fischer UR, Wieltschnig C, Kirschner AKT, Velimirov B (2006) Contribution of virus-induced lysis and protozoan grazing to benthic bacterial mortality estimated simultaneously in microcosms. Environ Microbiol 8:1394-1407

Flynn KJ, Davidson K, Cunningham A (1996) Prey selection and rejection by a microflagellate; implications for the study and operation of microbial food webs. J Exp Mar Biol Ecol 196:1-2

Fuhrman JA (1999) Marine viruses and their biogeochemical and ecological effects. Nature 399:541-548

Fuhrman JA, Noble R (1995) Viruses and protists cause similar bacterial mortality in coastal seawater. Limnol Oceanogr 40:1236-1242

Gallegos CL (1989) Microzooplankton grazing on phytoplankton in the Rhode River, Maryland: nonlinear feeding kinetics. Mar Ecol Prog Ser 57:23-33

Geider RJ, La Roche J (1994) The role of iron in phytoplankton photosynthesis, and the potential for iron-limitation of primary productivity in the sea. Photosynth Res 39: 275-301

Gifford DJ (1988) Impact of grazing by microzooplankton in the Northwest Arm of Halifax Harbour, Nova Scotia. Mar Ecol Prog Ser 47:249-258

Guixa-Boixereu N, Lysnes K, Pedros-Alio C (1999) Viral lysis and bacterivory during a phytoplankton bloom in a coastal water microcosm. Appl Environ Microbiol 65:1949-1958

Jacquet S, Hedal M, Iglesias-Rodriguez D, Larsen A, Wilson W, Bratbak G (2002) Flow cytometric analysis of an Emiliania huxleyi bloom terminated by viral infection. Aquat Microb Ecol 27:111-124

Jacquet S, Domaizon I, Personnic S, Ram ASP, Hedal M, Duhamel S, Sime-Ngando T (2005) Estimates of protozoan- and viral-mediated mortality of bacterioplankton in Lake Bourget (France). Freshw Biol 50:627-645

Kirchman DL (1999) Oceanography-Phytoplankton death in the sea. Nature 398:293-294

Kolber Z, Falkowski PG (1993) Use of active fluorescence to estimate phytoplankton photosynthesis in situ. Limnol Oceanogr 38:1646-1665

Kolber ZS, Prasil O, Falkowski PG (1998) Measurements of variable chlorophyll fluorescence using fast repetition rate techniques: defining methodology and experimental protocols. Biochim Biophys Acta 1367:88-106

Krause GH, Weis E (1991) Chlorophyll fluorescence and photosynthesis - the basics. Annu Rev Plant Physiol Plant Mol Biol 42:313-349

Kruskopf M, Flynn KJ (2006) Chlorophyll content and fluorescence responses cannot be used to gauge reliably phytoplankton biomass, nutrient status or growth rate. New Phytol 169:525-536

Landry M (1993) Estimating rates of growth and grazing mortality of phytoplankton by the dilution method. In: Kemp PF, Sherr BF, Sherr EB, Cole JJ (eds) Handbook of methods in aquatic microbial ecology. Lewis Publishers, Boca Raton, FL, p 715-722

Landry MR, Hassett RP (1982) Estimating the grazing impact of marine microzooplankton. Mar Biol 67:283-288

Landry MR, Monger BC, Selph KE (1993) Time-dependency of microzooplankton grazing and phytoplankton growth in the Subarctic Pacific. Prog Oceanogr 32:1-4

Landry MR, Kirshtein J, Constantinou J (1995) A refined dilution technique for measuring the community grazing impact of microzooplankton, with experimental tests in the central equatorial Pacific. Mar Ecol Prog Ser 120: 53-63

Lessard EJ, Murrell MC (1998) Microzooplankton herbivory and phytoplankton growth in the northwestern Sargasso Sea. Aquat Microb Ecol 16:173-188

Nagasaki K, Ando M, Itakura S, Imai I, Ishida Y (1994) Viral 
mortality in the final stage of Heterosigma akashiwo (Raphidophyceae) red tide. J Plankton Res 16:1595-1599

Pedros-Alio C, Calderon-Paz JI, Gasol JM (2000) Comparative analysis shows that bacterivory, not viral lysis, controls the abundance of heterotrophic prokaryotic plankton. FEMS Microbiol Ecol 32:157-165

Proctor LM, Fuhrman JA (1990) Viral mortality of marine bacteria and cyanobacteria. Nature 343:60-62

Rodda KM (1996) Temporal and spatial dynamics of Synechococcus spp. and Micromonas pusilla host-viral systems. MA thesis, University of Texas, Austin, TX

Rodríguez F, Fernandez E, Head RN, Harbour DS, Bratbak G, Heldal M, Harris RP (2000) Temporal variability of viruses, bacteria, phytoplankton and zooplankton in the western English Channel off Plymouth. J Mar Biol Assoc UK 80: 575-586

Sokal RR, Rohlf FJ (1995) Biometry: the principles and practice of statistics in biological research. WH Freeman, New York

Somerfield PJ, Clarke KR (1997) A comparison of some methods commonly used for the collection of sublittoral sediments and their associated fauna. Mar Environ Res 43: 145-156

Steward GF, Smith DC, Azam F (1996) Abundance and production of bacteria and viruses in the Bering and Chukchi Seas. Mar Ecol Prog Ser 131:287-300

Suttle CA (1992) Inhibition of photosynthesis in phytoplankton by the submicron size fraction concentrated from seawater. Mar Ecol Prog Ser 87:105-112

Suttle CA (2000) Ecological, evolutionary, and geochemical consequences of viral infection of cyanobacteria and eukaryotic algae. In: Hurst CJ (ed) Viral ecology. Academic Press, London, p 247-296

Suttle CA (2005) Viruses in the sea. Nature 437:356-361

Suttle CA, Chan AM (1993) Marine cyanophages infecting oceanic and coastal strains of Synechococcus:abundance, morphology, cross-infectivity and growth characteristics. Mar Ecol Prog Ser 92:99-109

Suttle CA, Chan AM (1994) Dynamics and distribution of cyanophages and their effect on marine Synechococcus spp. Appl Environ Microbiol 60:3167-3174

Suttle CA, Chan AM, Cottrell MT (1990) Infection of phytoplankton by viruses and reduction of primary productivity. Nature 347:467-469

Editorial responsibility: Gunnar Bratbak,

Bergen, Norway
Suttle CA, Chan AM, Rodda KM, Short SM, Weinbauer MG, Garza DR, Wilhelm SW (1996) The effect of cyanophages on Synechococcus spp. during a bloom in the western Gulf of Mexico. EOS Trans Am Geophys Union 76(Suppl): 207-208

Timmermans KR, Gerringa LJA, de Baar HJW, van der Wagt $B$ and others (2001) Growth rates of large and small southern ocean diatoms in relation to availability of iron in natural seawater. Limnol Oceangr 46:260-266

Tuomi P, Kuuppo P (1999) Viral lysis and grazing loss of bacteria in nutrient- and carbon-manipulated brackish water enclosures. J Plankton Res 21:923-937

Van Etten JL, Lane LC, Meints RH (1991) Viruses and viruslike particles of eukaryotic algae. Microbiol Rev 55: 586-620

Weinbauer MG, Hofle MG (1998) Significance of viral lysis and flagellate grazing as factors controlling bacterioplankton production in a eutrophic lake. Appl Environ Microbiol 64:431-438

Weinbauer MG, Peduzzi P (1995) Significance of viruses versus heterotrophic nanoflagellates for controlling bacterial abundance in the northern Adriatic Sea. J Plankton Res 17:1851-1856

Wells LE, Deming JW (2006) Significance of bacterivory and viral lysis in bottom waters of Franklin Bay, Canadian Arctic, during winter. Aquat Microb Ecol 43:209-221

Wilhelm SW, Suttle CA (1999) Viruses and nutrient cycles in the sea - viruses play critical roles in the structure and function of aquatic food webs. BioScience 49:781-788

Wilson WH, Tarran GA, Schroeder D, Cox M, Oke J, Malin G (2002) Isolation of viruses responsible for the demise of an Emiliania huxleyi bloom in the English Channel. J Mar Biol Assoc UK 82:369-377

Worden AZ, Binder BJ (2003) Application of dilution experiments for measuring growth and mortality rates among Prochlorococcus and Synechococcus populations in oligotrophic environments. Aquat Microb Ecol 30:159-174

Yakovleva I, Hidaka M (2004) Differential recovery of PSII function and electron transport rate in symbiotic dinoflagellates as a possible determinant of bleaching susceptibility of corals. Mar Ecol Prog Ser 268:43-53

Yentsch CS, Yentsch CM, Phinney DA, Lapointe BE, Yentsch SFW (2004) The odyssey of new production. J Exp Mar Biol Ecol 300:15-30

Submitted: December 5, 2006; Accepted: August 12, 2007 Proofs received from author(s): November 5, 2007 